\title{
Correction to: Colloidal Organic Matter and Metal(loid)s in Coastal Waters (Gulf of Trieste, Northern Adriatic Sea)
}

\author{
Katja Klun ${ }^{1} \cdot$ Ingrid Falnoga $^{2} \cdot$ Darja Mazej $^{2} \cdot$ Primož Šket $^{3} \cdot$ Jadran Faganeli $^{1}$
}

Published online: 10 July 2020

(c) Springer Nature B.V. 2020

\section{Correction to: Aquatic Geochemistry (2019) 25:179-194 https://doi.org/10.1007/s10498-019-09359-6}

\begin{abstract}
Large volumes of seawater were sampled in the Gulf of Trieste (northern Adriatic Sea) in order to study the interactions between colloidal organic matter (COM) and metal(loid)s (Me) in coastal waters. COM ( $>5 \mathrm{kDa}$ ) was isolated by ultrafiltration and characterized using ${ }^{1} \mathrm{H}$ NMR spectroscopy and elemental $\mathrm{C}_{\text {org }}$. and $\mathrm{N}_{\text {tot }}$. analyses. COM in the gulf represents about one quarter of the dissolved organic carbon (DOC), and according to ${ }^{1} \mathrm{H}$ NMR analysis, it is composed of polysaccharides (30-45\%), lipids (30-55\%), proteins and carboxyl-rich alicyclic molecules (CRAM) (15-20\%), and humics $(<1 \%)$. An accumulation of COM was observed in the late spring-early summer. The polysaccharide and lipid fractions increased up to twofold and the protein fraction decreased, reflected in a higher $\mathrm{C}_{\text {org. }} / \mathrm{N}_{\text {tot }}$ ( 28 , molar) ratio. Higher concentrations of humics were observed due to local freshwater discharges in spring. COM from the Isonzo/Soča River differed from the marine COM exhibiting higher protein/CRAM and higher humic contents. COM from the Isonzo/Soča mouth at salinities 16-33 was compositionally similar to marine COM. Analysis of Me, performed by ICP-MS and CVAFS (Hg), showed that $\mathrm{Hg}$ (nearly 100\%), $\mathrm{Cu}(20 \%), \mathrm{Cr}(10 \%)$, and Se (10\%) have the highest Me affinity to colloids. Similar to $\mathrm{COM}, \mathrm{Hg}$ and $\mathrm{Cu}$ rapidly increased till summer due to their sequestration in accumulated $\mathrm{COM}$ (transfer to particulate phase). The observed $\mathrm{Me} / \mathrm{C}_{\text {org }}$. ratios $(\mathrm{Co}, \mathrm{Cd}, \mathrm{Hg}<\mathrm{U}, \mathrm{Cr}, \mathrm{Ni}$,
\end{abstract}

For reason beyond the control of the authors or the editors, the article titled "Colloidal Organic Matter and Metal(loid)s in Coastal Waters (Gulf of Trieste, Northern Adriatic Sea)" by Katja Klun1 · Ingrid Falnoga2 · Darja Mazej2 · Primož Šket3 · Jadran Faganeli1 (https://doi.org/10.1007/s10498-019-09359 -6) was published in the regular issue Vol. 25 issue 5-6 instead of this special section, where it was originally scheduled to appear. Therefore, the full article is reprinted here.

The original article can be found online at https://doi.org/10.1007/s10498-019-09359-6.

Jadran Faganeli

jadran.faganeli@nib.si

1 Marine Biological Station, National Institute of Biology, Fornace 41, 6330 Piran, Slovenia

2 Department Environmental Sciences, Jozef Stefan Institute, Jamova 39, 1000 Ljubljana, Slovenia

3 National Institute of Chemistry, Hajdrihova 18, 1000 Ljubljana, Slovenia 
$\mathrm{Mn}<\mathrm{As}, \mathrm{Zn}, \mathrm{Cu}, \mathrm{V}<\mathrm{Se}, \mathrm{Al}, \mathrm{Fe}$ ) differ somewhat from those of the Irving-Williams series and can be explained by the composition of COM and variable background concentrations of studied Me in the northern Adriatic. Data from the salinity gradient in the metal-contaminated (especially $\mathrm{Hg}, \mathrm{Pb}, \mathrm{Zn}$ ) Isonzo/Soča mouth showed flocculation of $\mathrm{Al}$ and $\mathrm{Ba}$ and desorption of $\mathrm{V}, \mathrm{Co}, \mathrm{As}, \mathrm{Se}, \mathrm{Cs}, \mathrm{U}$, and $\mathrm{Hg}$, from the riverine particles with increasing ionic strength, while $\mathrm{Fe}, \mathrm{Mn}, \mathrm{Cu}, \mathrm{Cr}, \mathrm{Ni}, \mathrm{Zn}, \mathrm{Cd}$, and $\mathrm{Pb}$ did not correlate with salinity.

Keywords Colloidal organic matter - Dissolved organic carbon $\cdot$ NMR $\cdot$ Metals $\cdot$ Metalloids $\cdot$ Northern Adriatic Sea

\section{Introduction}

Only a small fraction of dissolved metals in seawater is present as free hydrated cations and in inorganic complexes (Donat and Bruland 1995). A great quantity of metals and metalloids (metal(loid)s-Me) in seawater is associated with organic matter (Stordal et al. 1996; Morel and Price 2003; Ravichandran 2004; Lamborg et al. 2004) influencing their biogeochemical behavior (Wells 2002; Fitzgerald et al. 2007). The size ranges that define the dissolved (DOM), colloidal (COM), and particulate organically (POM) bonded metals are nominal (Verdugo et al. 2004) and based on the pore size or the molecular weight cutoff of the filtration procedure employed (Aiken 2006). In addition to analytical difficulties, due to low concentration levels of metals and DOM in seawater, the compositional and structural complexity of DOM, consisting of various molecules of different sizes, shapes, conformations, and molecular weights and their separation, is a research challenge to determine factors governing these processes. Earlier investigations did not consider the distribution (continuum) of particles in natural waters discriminating only between particulate and dissolved phases. The development of separation procedures and analytical methods in metal-DOM investigations (Guentzel et al. 1996; Stolpe et al. 2010) and the complexometric determination of stability constants (Lamborg et al. 2004; Han et al. 2006) showed that an important fraction of dissolved metals in natural waters is bonded onto colloids (macromolecules) containing various binding sites (Wells 2002; Doucet et al. 2007). They are important in natural waters since they exhibit larger surface area and higher abundance compared to particles as well as being more reactive compared to particles and aggregating to macrogels/macroaggregates (Filella 2007).

The interactions between metals and organic matter are largely dependent on the chemical composition and structure of organic matter. The organic components contain various potential bonding sites with a range of binding constants (van Leeuwen and Buffle 2009). These seem dependent on the central heteroatom $(\mathrm{O}, \mathrm{N}, \mathrm{S})$, structure of neighboring groups (aliphatic, aromatic, electron acceptor and donor), and stereochemistry (Aiken 2006). The bonding of metals, especially $\mathrm{Hg}$, in natural waters is particularly dependent on quantitatively small DOM fractions containing thiol groups, but only a smaller part of reduced S groups, often in excess, strongly binds metals (Skyllberg 2012). The variability of the nature and the content of DOM in various aquatic environments with special reference to polarity and aromacity of molecules are therefore important factors governing the metal and DOM reactivity. The mechanisms of these processes and transformation pathways are not completely known at present (Wells 2002; Doucet et al. 2007).

The aim of this study was to investigate the interaction of COM with metals and metalloids (metal(loid)s) as a function of the COM composition and metal concentrations 
present in coastal waters, using the Gulf of Trieste (northern Adriatic Sea) as an example. It is affected by various metal(loid)s, especially $\mathrm{Hg}$ introduced by the Isonzo/Soča river inflow as a consequence of nearly 500 years of cinnabar mining and smelting activity in Idrija (NW Slovenia), the second largest $\mathrm{Hg}$ mine in the world (Hines et al. 2000; Horvat et al. 2002; Faganeli et al. 2003; Covelli et al. 2006), and $\mathrm{Pb}$ and $\mathrm{Zn}$ in Raibel (NE Italy). Metal-organic matter interactions are thought to be important since they are a significant metal immobilization pathway leading to lower metal bioavailability and thus lower activity in biogeochemical processes and transport in food webs (Lamborg et al. 2004; Miller et al. 2007) as well as increasing their removal rate from the seawater column (Wen et al. 1997). Conversely, marine DOM as a bacterial substrate may also enhance $\mathrm{Hg}$ methylation and reduction activities (Graham et al. 2012; Schartup et al. 2015; Bratkič et al. 2018). Degradation of the colloids with bound metals would, on the other hand, release them again into the water phase.

\section{Materials and Methods}

\subsection{Study Site and Sampling}

The Gulf of Trieste is a shallow marine basin in the northernmost part of the Adriatic Sea (Fig. 1) approximately $500 \mathrm{~km}^{2}$ in area with a maximum depth of $25 \mathrm{~m}$ and is partially isolated from the rest of the northern Adriatic Sea by a shoal extending SE-NW, from the Istrian peninsula to the Grado-Marano Lagoon. Vertical temperature and salinity gradients in late summer result in bottom water oxygen depletion and occasionally hypoxia and even anoxia. The main circulation is cyclonic and the outflow of seawater mostly occurs along the shallow northern coast after mixing with river waters (Solidoro et al. 2009). The mean seawater exchange rate in the gulf is about 4 weeks. The main freshwater inflow is from the Isonzo/Soča River in the north with an average flow of $82 \mathrm{~m}^{3} \mathrm{~s}^{-1}$ exhibiting late spring and autumn floods governed by snowmelt and rain, respectively. The second tributary is Timavo River, entering the gulf in the northeastern side with an average flow of approximately $30 \mathrm{~m}^{3} \mathrm{~s}^{-1}$. Smaller coastal rivers entering the gulf on its eastern side are the Rosandra and the Ospo (discharging into the Bay of Muggia), the Rižana (discharging into the Bay of Koper), and the Dragonja (discharging into the Bay of Piran) with average flows ranging between 1 and $4 \mathrm{~m}^{3} \mathrm{~s}^{-1}$ (Cozzi et al. 2012).

Large (90-100 L) seawater samples were collected monthly from January to December 2012 from a depth of 19 m, 3 m above the bottom, at the Marine Biological Station oceanographic buoy Vida (sampling site F0) located in the southern part of the Gulf of Trieste $\left(45^{\circ} 32^{\prime} 55,68^{\prime \prime} \mathrm{N}, 13^{\circ} 33^{\prime} 1,89^{\prime \prime} \mathrm{E}\right)$ approximately 1.2 nautical miles off Piran (Fig. 1). The average winter and summer seawater temperatures at the sampling depth were $11^{\circ} \mathrm{C}$ and $17{ }^{\circ} \mathrm{C}$, respectively, and the salinity during the whole sampling period varied only slightly between 37.7 and 37.8. Water samples in the Isonzo/Soča River (Fig. 1) were collected at salinity of 0.2 and those in the Isonzo/Soča River mouth (Fig. 1) at depths of $0,0.5$ and $1 \mathrm{~m}$ at salinities of 16, 26 and 33, respectively, in July 2013 during low flow $\left(50 \mathrm{~m}^{3} \mathrm{~s}^{-1}\right)$. All samples were collected using Niskin-X samplers.

Water samples were first gently vacuum-filtered through $0.45-\mu \mathrm{m}$ pore-size Millipore HA membrane filters to isolate suspended particulate matter (SPM). To isolate colloids, the filtrates were additionally gently vacuum-filtered through $0.22-\mu \mathrm{m}$ Nucleopore filters and successively ultrafiltered through a membrane with a nominal molecular weight cutoff 


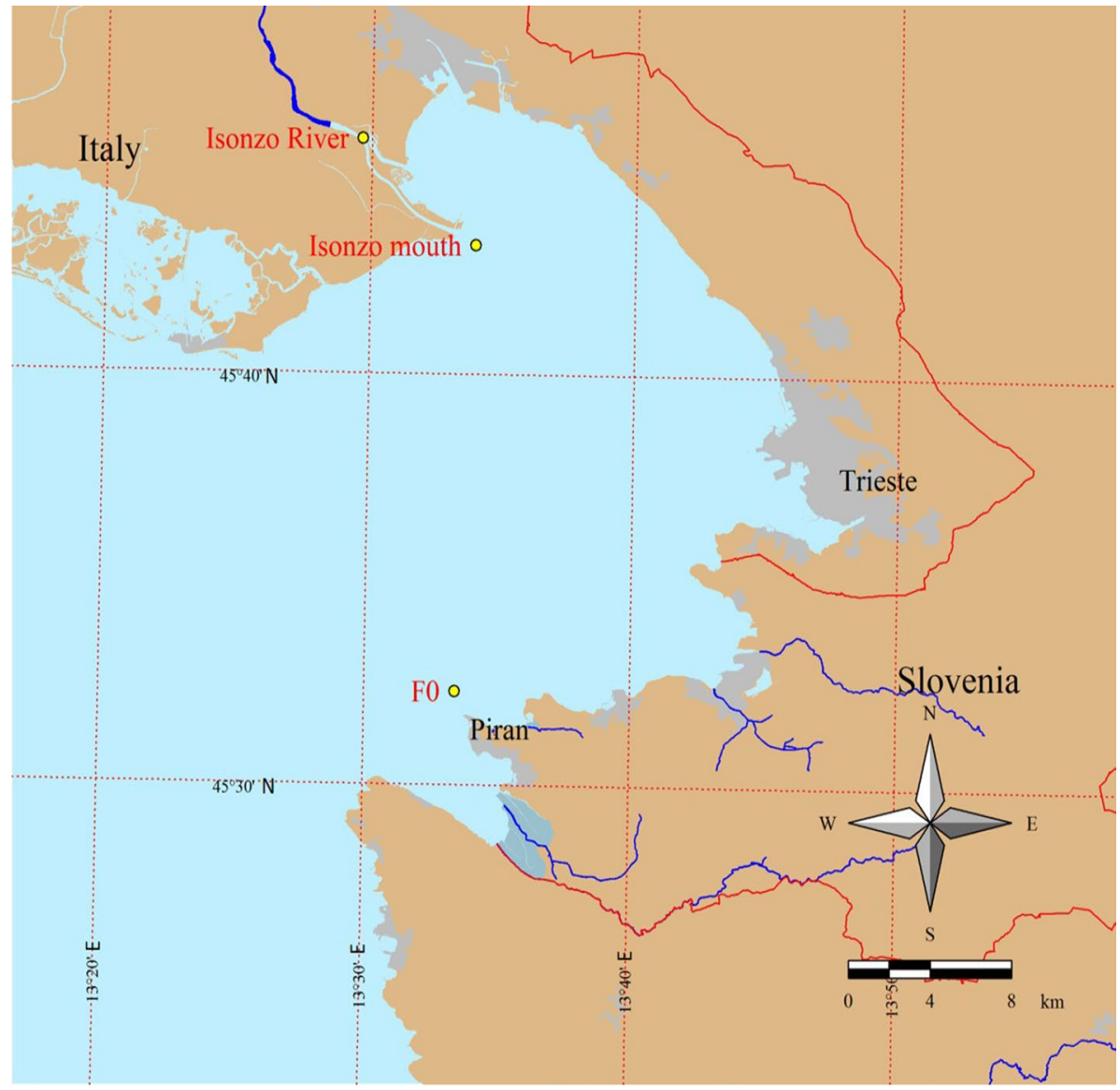

Fig. 1 Map of the Gulf of Trieste (northern Adriatic Sea) with sampling sites: Oceanographic buoy Vida (F0), Isonzo/Soča River and mouth

(MWCO) of $5 \mathrm{kDa}$ using six Vivascience Vivaflow 200 units (Sartorius) with three Masterflex S/L membrane pumps (Cole-Palmer) at a flow rate of $300 \mathrm{ml} \mathrm{min}^{-1}$ at $2.5 \mathrm{bar}$ at $20{ }^{\circ} \mathrm{C}$. The average concentration factor $(\mathrm{CF})$ was 65 . Retentates for COM characterization were freeze-dried and desalted by dialysis (Engel and Handel 2011) in Milli-Q water for $18 \mathrm{~h}$ at $4{ }^{\circ} \mathrm{C}$ using MWCO $1 \mathrm{kDa}$ RC membranes (Spectrapor 7, Spectrum Lab). The surrounding Milli-Q water was exchanged twice after 2 and $4 \mathrm{~h}$ to reduce salinity from 37 to 0.2 . A schematic diagram showing the processing procedure and operational terms used in this study is depicted in Fig. 2.

\subsection{Analyses}

The ETHOS 1 (MILESTONE) microwave digestion system was used for the digestion and extraction of metal(loid)s. An amount of sample was weighed in acid pre-cleaned Teflon tubes and $1 \mathrm{ml}$ of conc. $\mathrm{HNO}_{3}$ (s.p., Merck) and $1 \mathrm{ml}$ of $\mathrm{H}_{2} \mathrm{O}_{2}(30 \%$, Merck) were added. 


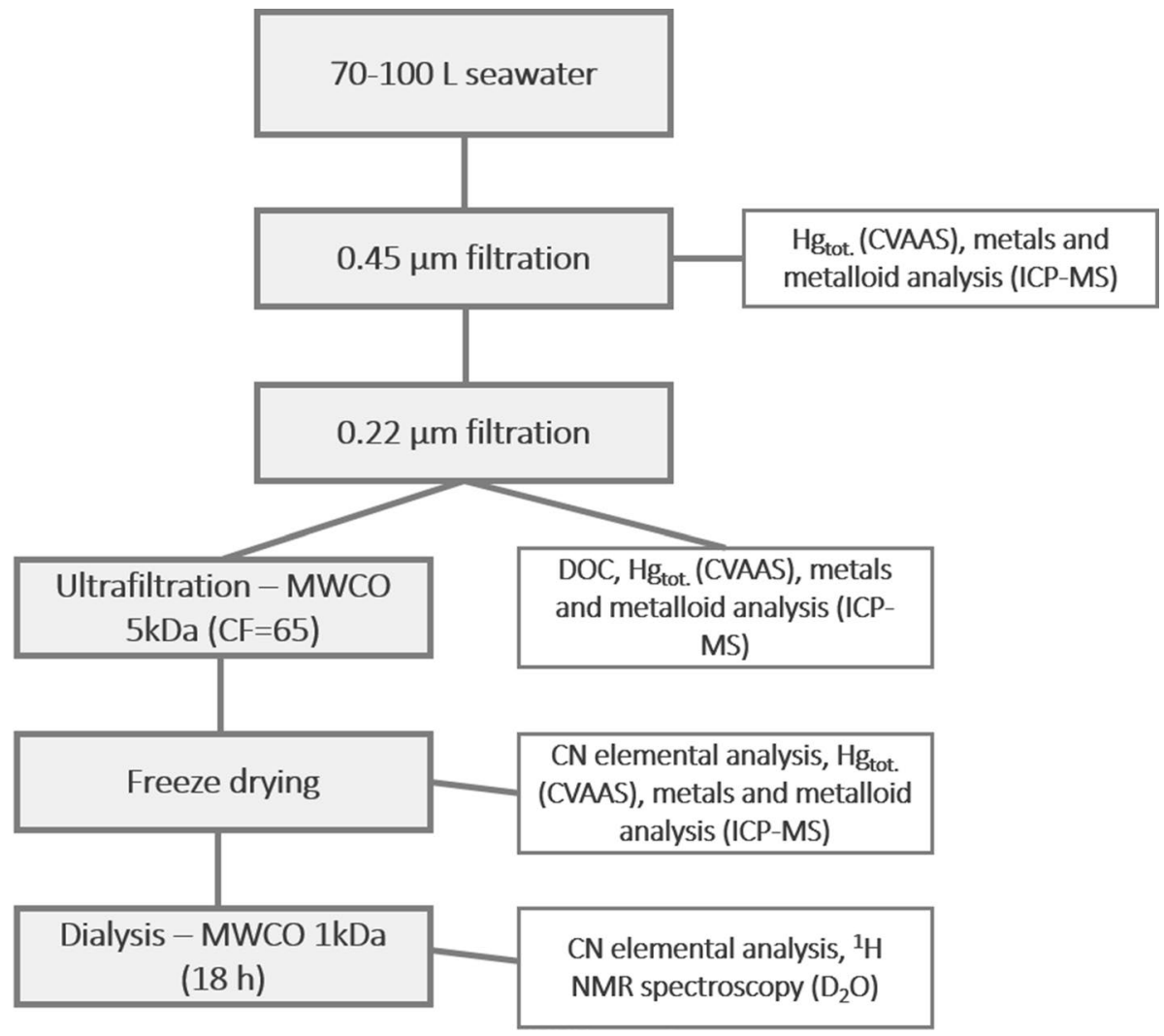

Fig. 2 A schematic diagram showing the processing procedure and operational terms used in this study

Microwave digestion conditions were as follows: $35 \mathrm{~min}$ ramp to $220{ }^{\circ} \mathrm{C}$ and hold at that temperature for $20 \mathrm{~min}$. The maximum power of the microwave system was $1200 \mathrm{~W}$ and was automatically temperature controlled. After digestion, the samples were left to cool, and the content of Teflon tubes was quantitatively transferred to 10-ml tubes where Milli$\mathrm{Q}$ water was added. For quality control and yield calculation, we used certified reference material (TORT-2), lobster hepatopancreas, from the National Research Council Canada (Table 1). Inductively coupled plasma mass spectrometry (ICP-MS) was used to determine trace metal and metalloid contents. Prior to measurement, the standard calibration solutions were prepared from ICP Multi Element Standard solution XXI (CertiPUR, Merck). Measurements were done using an Agilent 7500ce instrument with an octopole reaction cell and a Babington spray chamber, which allows for the direct analyses of seawater. To reduce interferences accompanying analyses, a He mode was used while analyzing $\mathrm{Cd}, \mathrm{Ni}$, $\mathrm{Pb}$, As, $\mathrm{Co}, \mathrm{Cr}, \mathrm{Cu}, \mathrm{Mo}$, and $\mathrm{Zn}$ contents and $\mathrm{H}_{2}$ mode in Se analyses. Quality control was ensured using a certified reference material available CASS-5, Nearshore Seawater for Trace Elements, from National Research Council Canada (Ottawa, Ontario, Canada) (Table 1). For determination of $\mathrm{Hg}_{\text {tot }}$ levels, a double amalgamation system and detection with cold vapor atomic fluorescence (CV AFS) were used. Briefly, after the decomposition of the samples in the presence of strong acids, $\mathrm{Hg}^{2+}$ is reduced to volatile elemental mercury $\left(\mathrm{Hg}^{0}\right)$ with an excess of $\mathrm{SnCl}_{2}$ (Horvat et al. 1991). Elemental mercury is concentrated 
Table 1 Certified and measured values for elements in certified TORT-2 and CASS-5 reference materials from National Research Council of Canada

\begin{tabular}{|c|c|c|c|c|}
\hline Element & Certified & Measured & Certified & Measured \\
\hline \multicolumn{3}{|l|}{ TORT-2 $\left(\mu \mathrm{g} \mathrm{g}^{-1}\right)$} & \multicolumn{2}{|l|}{$C A S S-5\left(\mu \mathrm{g} \mathrm{L}^{-1}\right)$} \\
\hline $\mathrm{V}$ & $1.64 \pm 0.19$ & 1.91 & $1.32 \pm 0.14^{*}$ & $1.31 \pm 0.20^{*}$ \\
\hline $\mathrm{Cr}$ & $0.77 \pm 0.15$ & 0.72 & $0.606 \pm 0.013$ & $0.777 \pm 0.101$ \\
\hline $\mathrm{Mn}$ & $13.6 \pm 1.2$ & 13.3 & $2.62 \pm 0.20$ & $2.75 \pm 0.15$ \\
\hline $\mathrm{Fe}$ & $105 \pm 13$ & 112 & $1.44 \pm 0.11$ & $1.49 \pm 0.13$ \\
\hline $\mathrm{Co}$ & $0.51 \pm 0.09$ & 0.55 & 0.095 & $0.098 \pm 0.009$ \\
\hline $\mathrm{Ni}$ & $2.50 \pm 0.19$ & 2.16 & $0.330 \pm 0.023$ & $0.335 \pm 0.030$ \\
\hline $\mathrm{Cu}$ & $106 \pm 10$ & 102 & $0.880 \pm 0.053^{*}$ & $1.14 \pm 0.17^{*}$ \\
\hline $\mathrm{Zn}$ & $180 \pm 6$ & 188 & $0.719 \pm 0.068$ & $0.702 \pm 0.105$ \\
\hline As & $21.6 \pm 1.8$ & 26.8 & $1.24 \pm 0.09$ & $1.45 \pm 0.14$ \\
\hline $\mathrm{Se}$ & $5.63 \pm 0.67$ & 8.03 & $0.50 \pm 0.05^{*}$ & $0.62 \pm 0.09^{*}$ \\
\hline $\mathrm{Cd}$ & $26.7 \pm 0.6$ & 29.2 & $0.522 \pm 0.044^{*}$ & $0.566 \pm 0.057 *$ \\
\hline $\mathrm{Pb}$ & $0.35 \pm 013$ & 0.41 & $0.511 \pm 0.045$ & $0.567 \pm 0.051$ \\
\hline \multicolumn{3}{|l|}{$B C R-61\left(\mu \mathrm{g} \mathrm{g}^{-1}\right)$} & \multicolumn{2}{|l|}{$B C R-579\left(\mathrm{ng} \mathrm{L}^{-1}\right)$} \\
\hline $\mathrm{Hg}$ & $0.23 \pm 0.02$ & $0.233 \pm 0.017$ & $1.9 \pm 0.5$ & $1.96 \pm 0.03$ \\
\hline \multicolumn{5}{|l|}{ IAEA140/TM $\left(\mu \mathrm{g} \mathrm{g}^{-1}\right)$} \\
\hline $\mathrm{Hg}$ & $0.038 \pm 0.006$ & $0.039 \pm 0.002$ & & \\
\hline
\end{tabular}

For $\mathrm{Hg}$ determinations three reference materials were used, BCR-61 (IRMM), BCR-579 (IRMM) and IAEA-140/TM (IAEA). Results are presented as arithmetical means of two determinations for TORT-2, three determinations \pm standard deviation for BCR-579 and six determinations \pm SD for CASS-5, BCR-61, and IAEA 140/TM, respectively

*Since in the certified reference material the concentrations were too low, the material was spiked with $0.5 \mu \mathrm{g} \mathrm{L}-1$

on a gold trap and detected after desorption at $600{ }^{\circ} \mathrm{C}$ by CV AFS (Tekran mod. 2500). For method validation and further quality and accuracy control, three commercially available reference materials were used, aquatic moss (BCR-6, IRMM), coastal seawater (BCR579, IRMM), and seaweed (IAEA-140/TM, IAEA) (Table 1). As an external standard, gas-phase $\mathrm{Hg}\left(\mathrm{Hg}^{0}\right)$ (Tekran, model 2505 mercury vapor calibration unit) kept at $10{ }^{\circ} \mathrm{C}$ was used. Detection limits for microwave digested and undigested samples are reported in Koron et al. (2013).

${ }^{1} \mathrm{H}$ NMR spectra of dialyzed COM samples were obtained on an Agilent Technologies VNMRS $800 \mathrm{MHz}$ NMR spectrometer in $\mathrm{D}_{2} \mathrm{O}$ at a temperature of $298 \mathrm{~K}$ using cold probe. Standard 1D ${ }^{1} \mathrm{H}$ NMR spectra were acquired using DPFGSE solvent suppression. The experimental conditions were: number of scans 256 , pulse width $7.7 \mathrm{~ms}$, spectral width $16,000 \mathrm{~Hz}$, acquisition time $1 \mathrm{~s}$ and pulse delay $1.5 \mathrm{~s} . \mathrm{C}_{\text {org }}$. and $\mathrm{N}_{\text {tot }}$ in COM were analyzed using an Elementar vario MICRO CUBE CHNS analyzer at a combustion temperature of $1020{ }^{\circ} \mathrm{C}$ after vapor phase acidification with $1 \mathrm{M} \mathrm{HCl}$, calibrated using sulfanilamide and quality control ensured with Algae (Spirulina) OAS (IVA Analysentechnik e.K.). DOC was analyzed by a high-temperature catalytic method using Shimadzu TOC 5000A analyzer after acidifying samples with $6 \mathrm{M} \mathrm{HCl}$ (Sugimura and Suzuki 1988), calibrated using K-phthalate and quality control ensured with CRM (University of Miami, Fl). Precision of both methods was $3 \%$. 


\section{Results and Discussion}

\subsection{Colloidal Organic Matter}

COC levels increased by nearly twofold from the winter to summer months due to the microbial degradation resistance and a lag in increased bacterial production in late summer (Fonda Umani et al. 2007; Tinta et al. 2014). High DOC concentrations are generally found in late spring-early summer, but high concentrations of COC continued throughout the whole summer. In summer, when the gulf is characterized by high DOC (Faganeli and Herndl 1991; De Vittor et al. 2008) and to a lesser extent higher POC (Posedel and Faganeli 1991; Lipizer et al. 2012) concentrations, the COM can be further aggregated. DOC and POC in the gulf mostly originate from phytoplankton (Faganeli et al. 2009) mainly composed of diatoms and nanoflagellates (Mozetič et al. 2012). The phytoplankton biomass exhibits early spring and autumn maxima, while a higher primary productivity period normally appears throughout the entire spring till summer (Fonda Umani et al. 2007). COM was found to be according to $\delta^{13} \mathrm{C}_{\text {org }}$. values, ranging between -21 and $-26 \%$, prevalently of phytoplankton origin $\left(\delta^{13} \mathrm{C}_{\text {org }}-21 \%\right.$ ) only in winter (Klun et al. 2015). In other periods, an increased terrigenous influence and the prevalence of lipids in COM, generally known with lower $\delta^{13} \mathrm{C}_{\text {org }}$. values (Hoefs 2009), were encountered. In the Isonzo/Soča River (Table 2), the concentration of DOC $\left(114 \mu \mathrm{mol} \mathrm{L}^{-1}\right)$, also previously reported by Bonzongo et al. (2002), was nearly at the same level as in seawater in the gulf $\left(58-119 \mu \mathrm{mol} \mathrm{L}^{-1}\right)$ and in the Isonzo/Soča River mouth $\left(66-101 \mu \mathrm{mol} \mathrm{L}{ }^{-1}\right)$. Conversely, the $\%$ of COC in DOC in the river and mouth were lower (9-16\%) compared to seawater $(25 \%)$. These contributions are on average lower than those reported by Repeta et al. (2002) for freshwaters (approx. 50\%) and similar to values reported by Mopper et al. (2007) for seawater.

According to ${ }^{1} \mathrm{H}$ NMR spectroscopy (Fig. 3), the lipid fraction of COM $(\delta=0-1.8 \mathrm{ppm})$ proportionally increased by $44 \%$ toward late spring-early

Table 2 Colloidal $\mathrm{C}_{\text {org. }}(\mathrm{COC})$ and $\mathrm{N}_{\text {tot. }}$ concentrations, $\mathrm{C}_{\text {org. }} / \mathrm{N}_{\text {tot. }}$ ratio and COC/DOC in the Isonzo/Soča River and mouth, and in the southern part of the Gulf of Trieste (sampling site F0, Klun et al. 2015)

\begin{tabular}{|c|c|c|c|c|c|}
\hline Locality salinity & Fraction & $\begin{array}{l}\mathrm{C}_{\text {org. }} \\
\left(\mu \mathrm{mol} \mathrm{L}{ }^{-1}\right)\end{array}$ & $\begin{array}{l}\mathrm{N}_{\text {tot. }} \\
\left(\mu \mathrm{mol} \mathrm{L}{ }^{-1}\right)\end{array}$ & $\begin{array}{l}\mathrm{C} / \mathrm{N} \\
\text { (molar) }\end{array}$ & $\begin{array}{l}\mathrm{COC} / \mathrm{DOC} \\
(\%)\end{array}$ \\
\hline \multirow[t]{3}{*}{ Isonzo/Soča River } & $0.2 \mu \mathrm{m}$ filtrate & 113.6 & 26.2 & 4.3 & \multirow[t]{3}{*}{9.2} \\
\hline & $5 \mathrm{kDa}$ retentate & 10.5 & 0.9 & 11.3 & \\
\hline & $5 \mathrm{kDa}$ permeate & 130.3 & 27.3 & 4.8 & \\
\hline \multirow[t]{3}{*}{ Isonzo/Soča mouth 16} & $0.2 \mu \mathrm{m}$ filtrate & 66.3 & l & l & \multirow[t]{3}{*}{13.6} \\
\hline & $5 \mathrm{kDa}$ retentate & 9.0 & l & / & \\
\hline & $5 \mathrm{kDa}$ permeate & 106.9 & l & l & \\
\hline \multirow[t]{3}{*}{ Isonzo/Soča mouth 26} & $0.2 \mu \mathrm{m}$ filtrate & 90.6 & / & / & \multirow[t]{3}{*}{16.1} \\
\hline & $5 \mathrm{kDa}$ retentate & 14.6 & I & / & \\
\hline & $5 \mathrm{kDa}$ permeate & 83.9 & I & l & \\
\hline \multirow[t]{3}{*}{ Isonzo/Soča mouth 33} & $0.2 \mu \mathrm{m}$ filtrate & 100.7 & / & / & \multirow[t]{3}{*}{12.8} \\
\hline & $5 \mathrm{kDa}$ retentate & 12.9 & l & l & \\
\hline & $5 \mathrm{kDa}$ permeate & 91.4 & l & / & \\
\hline F0 38 & $5 \mathrm{kDa}$ retentate & $13.6-27.1$ & $1.1-5.2$ & $3.5-28.5$ & $16.3-32.4$ \\
\hline
\end{tabular}




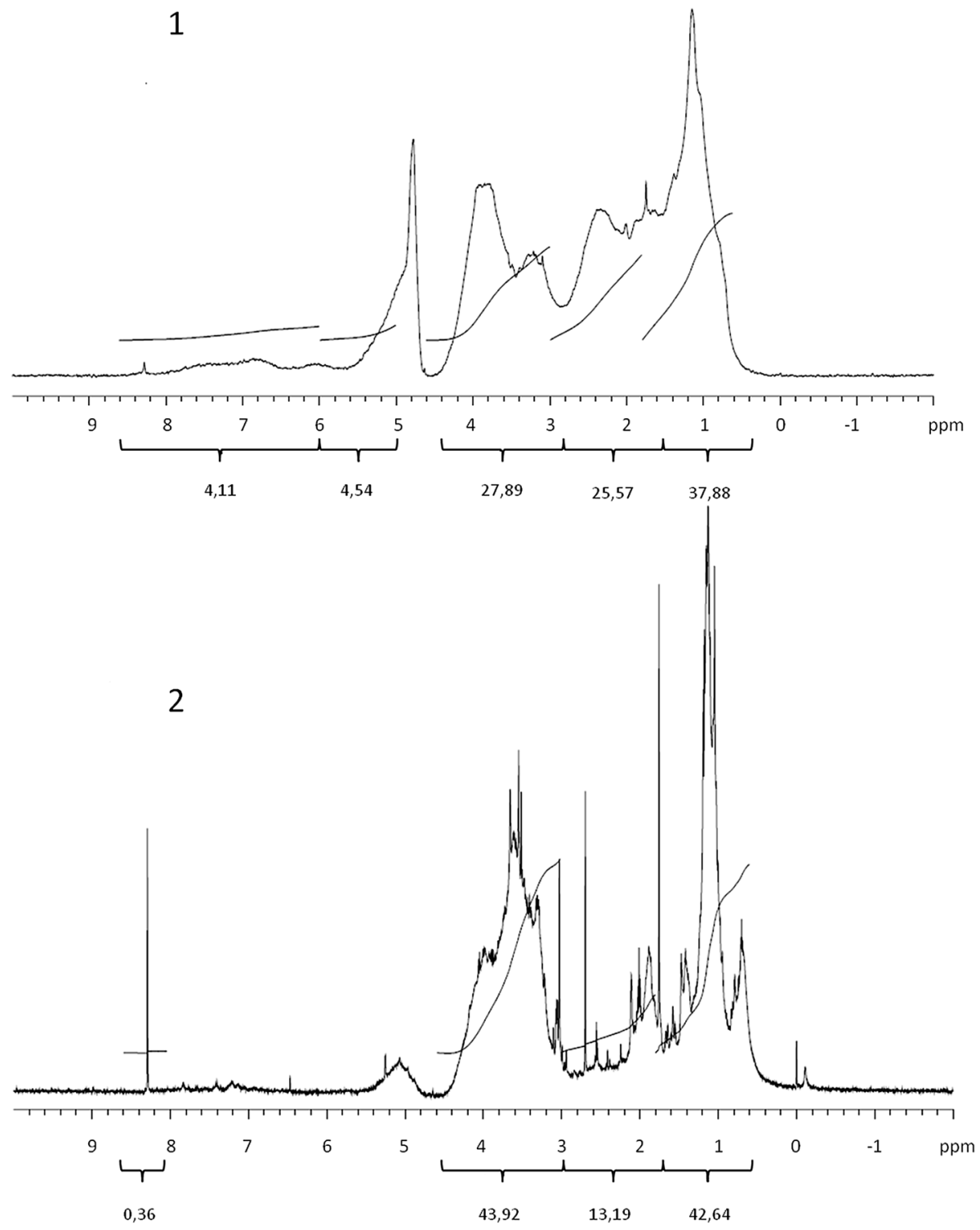

Fig. 3 Comparison of ${ }^{1} \mathrm{H}$ NMR spectra of COM from the Isonzo/Soča River (1) and mouth at salinity 26 (2)

summer, while the polysaccharide $(\delta=3-4.6 \mathrm{ppm})$ and protein $(\delta=1.8-3 \mathrm{ppm})$ fractions decreased, approximately by 18 and $40 \%$, respectively (Table 3 ), indicating the refractory property of the summer COM also supported by its high $\mathrm{C}_{\text {org. }} / \mathrm{N}_{\text {tot }}$. ratios (17-60, molar). The COM composition appears in general similar to the northern Adriatic macroaggregates (Kovac et al. 2002) and oceanic COM (Benner et al. 1992; Aluwihare et al. 1997). The refractory component at $\delta=1.8-3 \mathrm{ppm}$ can be composed of carboxylic-rich alicyclic organic molecules-CRAM thought to be the major 
Table 3 Distribution of the main groups of proton resonance in ${ }^{1} \mathrm{H}$ NMR spectra $(\delta / \mathrm{ppm})$ in COM from the Isonzo/Soča River and mouth and from the Gulf of Trieste (sampling site F0, Klun et al. 2015)

\begin{tabular}{lllll}
\hline Range & $\begin{array}{l}\text { Lipids } \\
\mathrm{HCH}_{2}-\mathrm{CH}_{2}{ }^{-}\end{array}$ & $\begin{array}{l}\text { Proteins/CRAM } \\
\text { HC-HCOR }\end{array}$ & $\begin{array}{l}\text { Polysaccharides } \\
\text { HC-OH } \\
\text { HC-O-C }\end{array}$ & $\begin{array}{l}\text { Humics } \\
\mathrm{H}_{\text {Arom. }}\end{array}$ \\
\hline S/ppm & $0-1.8$ & $1.8-3.0$ & $3.0-5.5$ & $6.0-8.5$ \\
Isonzo/Soča River & 37.9 & 25.6 & 32.4 & 4.1 \\
Isonzo/Soča mouth 16 & 39.3 & 13.2 & 46.9 & 0.5 \\
Isonzo/Soča mouth 26 & 42.6 & 13.2 & 43.8 & 0.4 \\
Isonzo/Soča mouth 33 & 41.3 & 13.8 & 44.3 & 0.6 \\
F0/Period & & & & \\
Jan'12 & 33.2 & 20.4 & 46.1 & 0.3 \\
Apr'12 & 38.4 & 14.8 & 45.9 & 0.9 \\
May'12 & 36.9 & 14.0 & 48.6 & 0.5 \\
Jun'12 & 43.1 & 12.6 & 43.8 & 0.5 \\
Jul'12 & 47.9 & 13.1 & 38.8 & 0.3 \\
Aug'12 & 44.8 & 15.1 & 39.3 & 0.8 \\
Sep'12 & 47.9 & 15.8 & 35.5 & 0.8 \\
Oct'12 & 42.9 & 14.5 & 41.7 & 0.4 \\
Nov'12 & 59.9 & 13.4 & 26.3 & 0.4 \\
Dec'12 & 46.4 & & 27.2 & \\
\hline
\end{tabular}

component of the lacustrine (Lam et al. 2007) and marine DOM (Hertkorn et al. 2007). In contrast to Repeta et al. (2002), we found some compositional differences between marine and riverine COM. It was especially notable in $>10$-fold higher humic content $(\delta=6-8.5 \mathrm{ppm})$ in the Isonzo/Soča river mouth samples and in the higher proportion of structural component at $\delta=1.8-3 \mathrm{ppm}$ (Table 3 ), likely composed of CRAM derived from cyclic and linear terpenoids (Lam et al. 2007). The lower resolution of the riverine $\mathrm{COM}{ }^{1} \mathrm{H}$ NMR spectrum compared to marine spectra (Fig. 3) could indicate the greater macromolecular/aggregated nature of riverine COC (Lam et al. 2007). The composition of COM at salinity 16 and higher salinities was similar to marine COM, suggesting flocculation of riverine colloids at a higher ionic strength.

\subsection{Metals and Metalloids in Dissolved and Colloidal Phases}

The concentrations of dissolved $\mathrm{Al}, \mathrm{Cr}, \mathrm{Mn}, \mathrm{Fe}, \mathrm{Cu}, \mathrm{Zn}, \mathrm{Se}$, and $\mathrm{Hg}$ in the gulf (Table 4) varied during the year, while those of $\mathrm{V}, \mathrm{Co}, \mathrm{Ni}, \mathrm{As}, \mathrm{Cd}, \mathrm{Cs}, \mathrm{Ba}$, and $\mathrm{U}$ were nearly constant. Among them, the concentrations of $\mathrm{Cr}, \mathrm{Mn}, \mathrm{Cu}$, and $\mathrm{Hg}$ increased in summer. The majority of dissolved metal(loid)s, except $\mathrm{Se}, \mathrm{Cu}, \mathrm{Zn}$, and $\mathrm{Ni}$, were at the same concentration level as previously reported by Koron et al. (2013) for the Gulf of Trieste and similar to those reported in other, including Mediterranean, estuarine, and coastal waters (Oursel et al. 2013; Stolpe et al. 2010; Wen et al. 1999) but substantially higher than those reported for the ocean surface (Donat and Bruland 1995). $\mathrm{Hg}$ (nearly 100\%), $\mathrm{Cu}(20 \%)$, $\mathrm{Cr}(11 \%)$, and Se (11\%) showed the highest percentages of colloidally bonded metal(loid) s. These levels are also comparable to those of Koron et al. (2013). In the Isonzo/Soča River (Table 5), dissolved metal concentrations were comparable to the world average river 
Table 4 Average metal and metalloid concentrations in dissolved, colloidal, and particulate (SPM) fractions $(N=11)$ from the southern part of the Gulf of Trieste (sampling site F0)

\begin{tabular}{lllll}
\hline & $\begin{array}{l}\text { Dissolved metal(loid)s } \\
(\mathrm{nmol} \mathrm{L}\end{array}$ & Colloids $\left(\mathrm{nmol} \mathrm{L}^{-1}\right)$ & $\begin{array}{l}\text { Colloidally bonded } \\
(\%)\end{array}$ & $\mathrm{SPM}\left(\mathrm{nmol} \mathrm{L}^{-1}\right)$ \\
\hline $\mathrm{Al}$ & $334 \pm 248$ & $2.9 \pm 2.9$ & 1.5 & 1595 \\
$\mathrm{~V}$ & 38 & $1.1 \pm 0.1$ & 3 & 1.5 \\
$\mathrm{Cr}$ & 12 & $0.8 \pm 0.3$ & 11 & 2.5 \\
$\mathrm{Mn}$ & 28 & $0.6 \pm 0.4$ & 7.5 & 16 \\
$\mathrm{Fe}$ & 223 & 17.0 & 7.6 & 342 \\
$\mathrm{Co}$ & 1 & $0.05 \pm 0.01$ & 5 & 0.2 \\
$\mathrm{Ni}$ & 15 & $0.5 \pm 0.1$ & 4 & 0.8 \\
$\mathrm{Cu}$ & 41 & $4 \pm 0.3$ & 20 & 1.5 \\
$\mathrm{Zn}$ & 71 & $1.7 \pm 0.7$ & 1.3 & 3.5 \\
$\mathrm{As}$ & 20 & $0.70 \pm 0.07$ & 3 & 0.2 \\
$\mathrm{Se}$ & 15 & $2.9 \pm 0.5$ & 11 & 0.05 \\
$\mathrm{Cd}$ & 1 & $0.010 \pm 0.003$ & 1 & 0.35 \\
$\mathrm{Cs}$ & $2 \pm 0.3$ & $0.030 \pm 0.004$ & 1.5 & $/$ \\
$\mathrm{Ba}$ & $46 \pm 38$ & $0.50 \pm 0.09$ & 1.5 & 0.75 \\
$\mathrm{U}$ & $13 \pm 1$ & $0.20 \pm 0.02$ & 1.7 & 0.4 \\
$\mathrm{Hg}$ & 0.003 & $0.004 \pm 0.003$ & 100 & 0.03 \\
\hline
\end{tabular}

Table 5 Metal and metalloid concentrations in dissolved, colloidal, and particulate (SPM) fractions from the Isonzo/Soča River

\begin{tabular}{lllll}
\hline & $\begin{array}{l}\text { Dissolved } \\
\text { metal(loid)s } \\
(\text { nmol L-1) }\end{array}$ & $\begin{array}{l}\text { Colloids } \\
\left.(\mathrm{nmol} \mathrm{L})^{-1}\right)\end{array}$ & $\begin{array}{l}\text { Colloidally } \\
\text { bonded }(\%)\end{array}$ & SPM $\left(\mathrm{nmol} \mathrm{L}^{-1}\right)$ \\
\hline $\mathrm{Al}$ & 2023 & 28.9 & 1.4 & 1595 \\
$\mathrm{~V}$ & 4 & 0.13 & 3 & 1.5 \\
$\mathrm{Cr}$ & 4 & 0.51 & 13 & 2.5 \\
$\mathrm{Mn}$ & 17 & 0.6 & 3.5 & 16 \\
$\mathrm{Fe}$ & 751 & 18.2 & 2.4 & 342 \\
$\mathrm{Co}$ & 0.5 & 0.025 & 5 & 0.2 \\
$\mathrm{Ni}$ & 6 & 0.78 & 17 & 0.8 \\
$\mathrm{Cu}$ & 8 & 2.6 & 33 & 1.5 \\
$\mathrm{Zn}$ & 77 & 2.63 & 3.4 & 3.5 \\
$\mathrm{As}$ & 1 & 0.06 & 6 & 0.2 \\
$\mathrm{Se}$ & 0.9 & BDL & BDL & 0.05 \\
$\mathrm{Cd}$ & 0.04 & 0.001 & 2.5 & 0.35 \\
$\mathrm{Cs}$ & 0.08 & 0.03 & 38 & $/$ \\
$\mathrm{Ba}$ & 166 & 6.27 & 3.8 & 0.75 \\
$\mathrm{U}$ & 0.26 & 0.001 & 0.4 & 0.4 \\
$\mathrm{Hg}$ & 0.003 & 0.004 & 100 & 0.03 \\
\hline $\mathrm{B}$ & & & & \\
\hline
\end{tabular}

$B D L$ below detection limit

values (Gaillardet et al. 2003) including small Mediterranean rivers (Oursel et al. 2013). $\mathrm{Hg}(100 \%), \mathrm{Cs}(38 \%)$, and $\mathrm{Cu}(33 \%)$ showed the highest affinity to colloids followed by $\mathrm{Ni}$ $(17 \%)$ and $\mathrm{Cr}(13 \%)$. 
For, $\mathrm{V}, \mathrm{Co}, \mathrm{Ni}, \mathrm{Cd}, \mathrm{Cs}, \mathrm{Ba}$ and $\mathrm{U}$ in the gulf's waters, the concentrations of colloidally bonded were approximately constant (Fig. 4), suggesting that the COM and DOM do not influence the fate of colloidal bonded meta(lloid)s since the concentration and composition of COM and DOM were temporarily changing (De Vittor et al. 2008; Klun et al. 2015). Conversely, the concentrations of $\mathrm{Al}, \mathrm{Cr}, \mathrm{Mn}, \mathrm{Fe}, \mathrm{Cu}, \mathrm{Zn}, \mathrm{Se}$, and $\mathrm{Hg}$ were temporarily changed probably originating from terrestrially sources (Fig. 4). $\mathrm{Hg}$ and $\mathrm{Cu}$ showed the highest affinity to colloidal organic matter, since they were positively correlated with COC $\left(\mathrm{R}_{\mathrm{Hg}}^{2}=0.56 ; \mathrm{R}_{\mathrm{Cu}}^{2}=0.68\right)$ reported in Klun et al. (2015). Hg is considered a soft metal with light polarizable outer electron orbitals, and it is bonded to soft ligands, i.e., sulfur-containing functional groups (Fitzgerald et al. 2007). $\mathrm{Cu}$ is a hard metal with heavy polarizable outer electron orbitals also bonded with high stability constants onto oxygen-containing functional groups (Midorikawa and Tanoue 1998a, b). CRAM rich in carboxylic groups are possible structural candidate. Previous FTIR analyses of COM from the Gulf of Trieste indicated the presence of $\mathrm{OH}$ (carbohydrates and lipids)-, $\mathrm{COOH}$ (proteins and
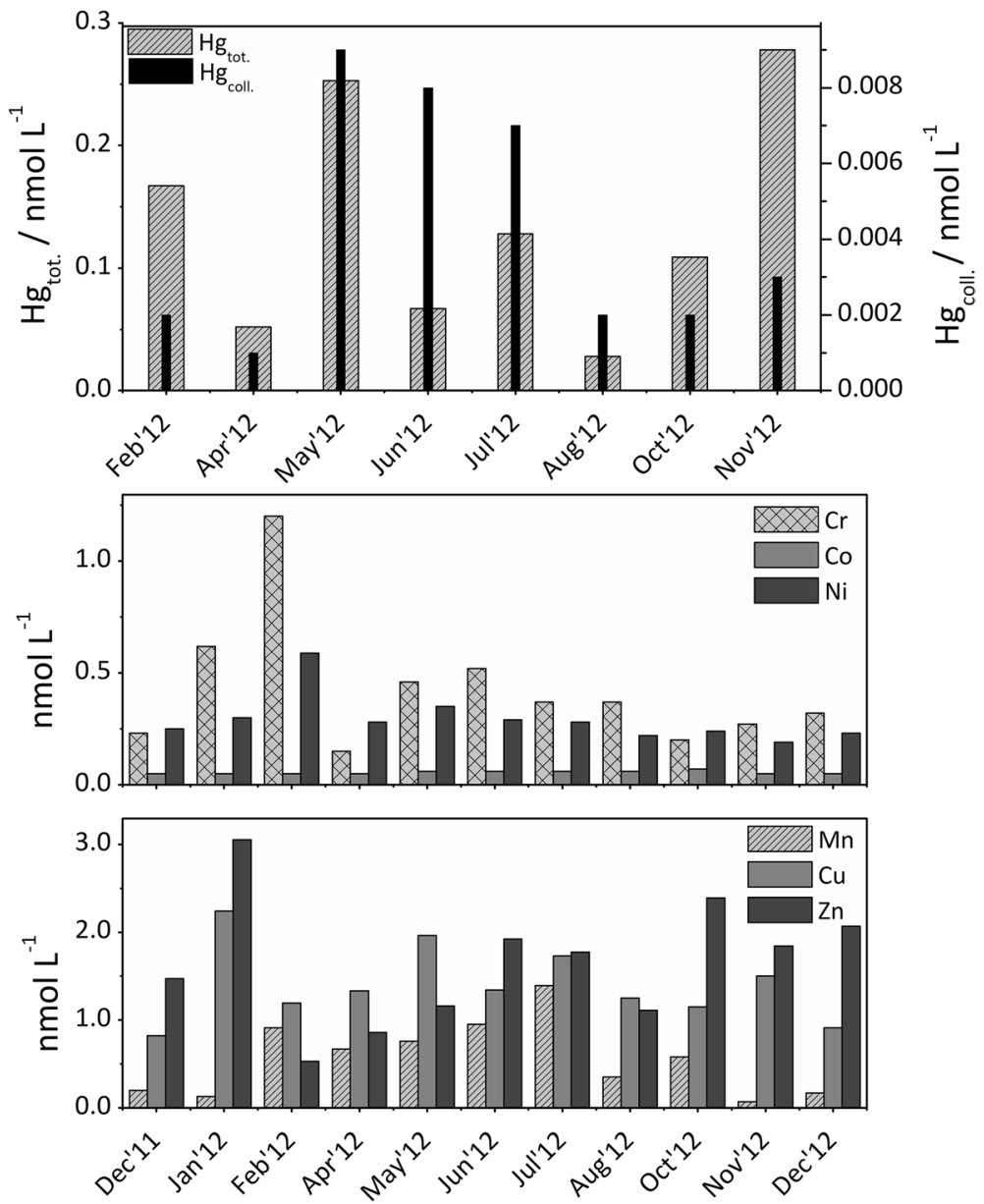

Fig. 4 Seasonal variations of total dissolved $\mathrm{Hg}\left(\mathrm{Hg}_{\text {tot. }}\right)$ and colloidal $\mathrm{Hg}\left(\mathrm{Hg}_{\text {coll. }}\right), \mathrm{Mn}, \mathrm{Cu}, \mathrm{Zn}, \mathrm{Cr}, \mathrm{Cr}, \mathrm{Co}$, and $\mathrm{Ni}$ at Oceanographic buoy Vida (F0) 
lipids)-, and NH (proteins)-containing functional groups (Klun et al. 2015). Colloidal Hg and $\mathrm{Cu}$ contents were increased in parallel with $\mathrm{COM}$ contents until early summer but afterward rapidly decreased. It appears that $\mathrm{Hg}$ and $\mathrm{Cu}$ in late summer can be less bonded to COM (> $5 \mathrm{kDa}$ ), but more to LMW DOC. In the Isonzo/Soča River mouth, the colloidal metal(loid)s V, Co, As, Se, Cs, U, and $\mathrm{Hg}$, with a positive correlation with salinity (Table 6), may originate from riverine particle desorption. Among them, $\mathrm{Hg}$ is significantly bonded onto the particulate phase in seawater and river water (Tables 4, 5) in oxides and sulfides (Stolpe et al. 2010). Oursel et al. (2013) showed desorption of $\mathrm{Cu}, \mathrm{Cd}, \mathrm{Co}, \mathrm{Pb}$, and $\mathrm{Zn}$ from suspended particles into dissolved phase in the salinity gradient of small Meditetrranean river mouths. Metals $\mathrm{Al}$ and $\mathrm{Ba}$ with a negative correlation with salinity may be transferred (flocculated) into particulate phase at higher ionic strengths (Sanudo-Wilhelmy et al. 1996). Colloidal Fe, Mn, $\mathrm{Cu}, \mathrm{Cr}, \mathrm{Ni}, \mathrm{Zn}, \mathrm{Cd}$, and $\mathrm{Pb}$ showed non-conservative mixing behavior with salinity. Similar was reported by Tang et al. (2002) for dissolved Ni, Zn, Pb, $\mathrm{Cd}$, and $\mathrm{Cu}$ in Galveston Bay and explained by their binding to reduced sulfur compounds.

\subsection{Metal(loid)/Organic Carbon (Me/ $\mathrm{C}_{\text {org. }}$ ) Ratios in Colloids}

Since $\mathrm{C}_{\text {org }}$. is a major organic constituent in marine colloids and carrier of accompanying metals (Guo and Santschi 1997; Ravichandran 2004), the metal concentrations can be normalized to $\mathrm{C}_{\text {org. }}$ (Table 7). This permits the comparison of our results with those in marine colloids reported elsewhere (Guo et al. 2000; Guo and Santschi 2007). The $\mathrm{C}_{\text {org. }}$ normalization reveals that the majority of $\mathrm{Me} / \mathrm{C}_{\text {org. }}$ ratios in the gulf ranged between $1 \times 10^{-5}$ and $8 \times 10^{-5}$. The exceptions are $\mathrm{Fe}(67)$, Al (21) and $\mathrm{Se}(14)$ at the upper side and $\mathrm{Co}(0.3), \mathrm{Cd}(0.04), \mathrm{Cs}(0.2)$ and $\mathrm{Hg}(0.02)$ at the lower side. For metals with constant concentration levels, $\mathrm{Me} / \mathrm{C}_{\text {org. }}$ ratios decreased in summer due to the increase in $\mathrm{C}_{\text {org. }}$ content. $\mathrm{Hg} / \mathrm{C}_{\text {org. }}$ ratio increased, up to fivefold, from winter to early summer as a consequence of higher COM content and higher available complexing

Table 6 Concentrations of colloidal metals and metalloids $\left(\mathrm{nmol} \mathrm{L}{ }^{-1}\right)$ in the Isonzo/Soča River and mouth and correlations between colloidal metal(loid)s and salinity including sampling point F0 (salinity 37) in the gulf $(N=5)$

\begin{tabular}{lllllllllll}
\hline Locality & Salinity & $\mathrm{Al}$ & $\mathrm{V}$ & $\mathrm{Cr}$ & $\mathrm{Mn}$ & $\mathrm{Fe}$ & $\mathrm{Co}$ & $\mathrm{Ni}$ & $\mathrm{Cu}$ & $\mathrm{Zn}$ \\
\hline Isonzo Mouth 33 & 33 & 18.63 & 1.02 & 0.63 & 1.55 & 12.79 & 0.07 & 0.75 & 0.82 & 6.91 \\
Isonzo Mouth 26 & 26 & 7.70 & 0.86 & 0.46 & 1.93 & 13.08 & 0.05 & 0.48 & 1.74 & 2.35 \\
Isonzo Mouth 16 & 16 & 23.97 & 0.43 & 0.33 & 1.99 & 5.83 & 0.03 & 0.33 & 0.95 & $\mathrm{BDL}$ \\
Isonzo/Soča River & 0.2 & 28.97 & 0.13 & 0.51 & 0.57 & 18.17 & 0.03 & 0.78 & 2.56 & 2.63 \\
Correlation versus Salinity $R^{2}$ & & -0.68 & 0.97 & 0.38 & 0.03 & 0 & 0.75 & 0.05 & -0.02 & 0.05 \\
\hline & Salinity & $\mathrm{Se}$ & $\mathrm{As}$ & $\mathrm{Cd}$ & $\mathrm{Cs}$ & $\mathrm{Ba}$ & $\mathrm{Pb}$ & $\mathrm{U}$ & $\mathrm{Hg}$ & \\
\hline Isonzo Mouth 33 & 33 & 1.87 & 0.64 & 0.05 & 0.06 & 1.61 & 0.04 & 0.21 & 0.003 & \\
Isonzo Mouth 26 & 26 & 1.00 & 0.55 & 0.03 & 0.04 & 2.08 & 0.02 & 0.21 & 0.004 & \\
Isonzo Mouth 16 & 16 & 0.37 & 0.28 & 0.01 & 0.01 & 3.35 & 0.01 & 0.11 & 0.002 & \\
Isonzo/Soča River & 0.2 & $\mathrm{BDL}$ & 0.12 & $\mathrm{BDL}$ & $\mathrm{BDL}$ & 6.27 & 0.02 & 0.01 & 0.001 & \\
Correlation versus Salinity $R^{2}$ & & 0.92 & 0.97 & 0.31 & 0.75 & -0.98 & 0.29 & 0.91 & 0.71 & \\
\hline
\end{tabular}

$B D L$ below detection limit 
Table 7 Comparison of average metal and metalloid affinity to COM $\left(\mathrm{Me} / \mathrm{C}_{\text {org. }} \times 10^{-5}\right.$; molar ratio, $\left.N=11\right)$ with previous studies in the Gulf of Trieste (Koron et al. 2013) and in the Gulf of Mexico and Mid-Atlantic Bight (Guo et al. 2000)

\begin{tabular}{lclll}
\hline & Gulf of Trieste & $\begin{array}{l}\text { Gulf of Trieste (Koron } \\
\text { et al. 2013) }\end{array}$ & $\begin{array}{l}\text { Gulf of Mexico (Guo } \\
\text { et al. 2000) }\end{array}$ & $\begin{array}{l}\text { Central Atlantic } \\
\text { (Guo et al. 2000) }\end{array}$ \\
\hline $\mathrm{Al}$ & $21.1 \pm 20.9$ & 62.3 & $2.8 \pm 2.5$ & $3.3 \pm 2.6$ \\
$\mathrm{~V}$ & $6.8 \pm 0.4$ & 6.1 & $0.26 \pm 0.31$ & $0.34 \pm 0.39$ \\
$\mathrm{Cr}$ & $5.4 \pm 8.8$ & 1.8 & $2.6 \pm 1.1$ & $20 \pm 24$ \\
$\mathrm{Mn}$ & $3.2 \pm 1.8$ & 1 & $0.23 \pm 0.18$ & $1.1 \pm 1,2$ \\
$\mathrm{Fe}$ & $66.9 \pm 31.9$ & $/$ & $/$ & $/$ \\
$\mathrm{Co}$ & $0.28 \pm 0.04$ & $/$ & $0.083 \pm 0.053$ & $0.12 \pm 0.01$ \\
$\mathrm{Ni}$ & $2.5 \pm 2.3$ & 2.5 & $1.6 \pm 1.0$ & $5.5 \pm 4.3$ \\
$\mathrm{Cu}$ & $7.4 \pm 2.8$ & 19.2 & $1.93 \pm 0.0$ & $2.5 \pm 1.9$ \\
$\mathrm{Zn}$ & $8.3 \pm 4.2$ & 8.9 & $8.8 \pm 6.7$ & $2.8 \pm 2.6$ \\
$\mathrm{As}$ & $3.6 \pm 0.8$ & 3.5 & $/$ & $/$ \\
$\mathrm{Se}$ & $14.1 \pm 3.1$ & 1.4 & $/$ & $/$ \\
$\mathrm{Cd}$ & $0.04 \pm 0.01$ & $/$ & $0.013 \pm 0.08$ & $0.059 \pm 0.052$ \\
$\mathrm{Cs}$ & $0.15 \pm 0.04$ & $/$ & $/$ & $/$ \\
$\mathrm{Ba}$ & $2.7 \pm 0.5$ & 3.8 & $0.031 \pm 0.014$ & $0.084 \pm 0.050$ \\
$\mathrm{U}$ & $1.1 \pm 0.2$ & 1.2 & $/$ & $/$ \\
$\mathrm{Hg}$ & $0.02 \pm 0.02$ & 0.03 & $/$ & $/$ \\
\hline
\end{tabular}

functional groups, for example $\mathrm{N}$-containing macromolecules (aminopolysaccharides) (Hunter and Beveridge 2008) carboxyl (Quigley et al. 2002) and especially S-containing functional groups (Xia et al. 1999; Alvarado Quiroz et al. 2006; Skyllberg 2012). Comparison with colloids in macroaggregates from the gulf (Koron et al. 2013) revealed higher values, especially for $\mathrm{Cr}, \mathrm{Mn}$, and $\mathrm{Ni}$, in macroaggregate interstitial water colloids due to a higher $\mathrm{COM}$ content in macroaggregates. The majority of $\mathrm{Me} / \mathrm{C}_{\text {org. }}$ ratios in the Isonzo/Soča River mouth were in the same order as those in the waters of the gulf with the exception of lower ratio of $\mathrm{Se}(3-15)$ and with higher ratios of $\mathrm{Al}(48-176), \mathrm{Fe}$ (43-100) and $\mathrm{Ba}(13-25)$ originating from Isonzo/Soča River (Table 7). High $\mathrm{Me} / \mathrm{C}_{\text {org. }}$ ratios of $\mathrm{Al}, \mathrm{Fe}$, and $\mathrm{Ba}$ may partially originate from inorganic colloids.

Some differences were observed between the Irving-Williams order of binding strength of metals with organic ligands, i.e., $\mathrm{Cd}, \mathrm{Mn}<\mathrm{Co}<\mathrm{Zn}, \mathrm{Ni}<\mathrm{Cu}<\mathrm{Hg}$, and our $\mathrm{Me} / \mathrm{C}_{\text {org. }}$ ratios in the gulf's waters, i.e., $\mathrm{Cd}, \mathrm{Co}, \mathrm{Cs}, \mathrm{Hg}<\mathrm{Ni}, \mathrm{U}, \mathrm{Cr}, \mathrm{Mn}, \mathrm{Ba}<\mathrm{Zn}$, $\mathrm{Cu}, \mathrm{As}, \mathrm{V}<\mathrm{Se}, \mathrm{Al}, \mathrm{Fe}$. Our order was more similar to plankton (Millero 2006) due to affinity of metals to the COM of the gulf, composed mainly of heteropolysaccharides and lipids of plankton origin (Klun et al. 2015), and specific concentration ranges of metal(loid)s in the waters of the gulf. The colloidal $\mathrm{Me} / \mathrm{C}_{\text {org. }}$ ratios order in the Isonzo/ Soča River were different $\mathrm{Hg}, \mathrm{Cs}, \mathrm{Cd}<\mathrm{U}<\mathrm{Co}<\mathrm{V}<\mathrm{Cr}, \mathrm{Mn}<\mathrm{Ni}<\mathrm{Cu}<\mathrm{Zn}<\mathrm{Ba}<\mathrm{Fe}<\mathrm{A}$ 1, more similar to reported metal-humic association in river waters (Hiraide et al. 1994) in accordance with higher humic and CRAM contents. Al may be bonded in inorganic colloids. Comparison with other marine areas (Table 7) shows that the affinity of metals $\mathrm{Al}, \mathrm{V}, \mathrm{Mn}, \mathrm{Co}, \mathrm{Cu}, \mathrm{Cd}$, and $\mathrm{Ba}$ onto colloids is higher in the Gulf of Trieste compared to the Gulf of Mexico and central Atlantic (Guo et al. 2000). This can be due to higher concentration levels of dissolved metal(loid)s and COM in the coastal waters of the Gulf of Trieste. 


\section{Conclusions}

COM in the Gulf of Trieste, isolated by ultrafiltration, represents about one quarter of dissolved organic carbon (DOC) and, according to ${ }^{1} \mathrm{H}$ NMR analysis, it is composed of polysaccharides (30-45\%), lipids (30-55\%), proteins and carboxyl-rich alicyclic molecules (CRAM) (15-20\%) and humics $(<1 \%)$. Higher concentrations of humics were observed due to local freshwater discharges in spring. COM from the Isonzo/Soča River, the principal tributary to the gulf, differed from the marine COM exhibiting higher protein/CRAM and higher humic contents. COM from the Isonzo/Soča River mouth at salinities of 16-33 was compositionally similar to marine COM. In the gulf, analysis of metal(loid)s, performed by ICP-MS and CVAFS (Hg), showed that $\mathrm{Hg}$ (nearly 100\%), $\mathrm{Cu}(20 \%), \mathrm{Cr}(10 \%)$ and $\mathrm{Se}(10 \%)$ have the highest affinity to colloids. Similarly to COM, the levels of colloidal $\mathrm{Hg}$ and $\mathrm{Cu}$ increased till summer, due to their sequestration in accumulated COM (transfer to particulate phase), but later decreased. The observed $\mathrm{Me} / \mathrm{C}_{\text {org. }}$ ratios $(\mathrm{Co}, \mathrm{Cd}, \mathrm{Hg}<\mathrm{U}$, $\mathrm{Cr}, \mathrm{Ni}, \mathrm{Mn}<\mathrm{As}, \mathrm{Zn}, \mathrm{Cu}, \mathrm{V}<\mathrm{Se}, \mathrm{Al}, \mathrm{Fe}$ ) differ somewhat from those of the Irving-Williams series and can be explained by the composition of COM and variable background concentrations of studied metal(loid)s in the northern Adriatic. Data from the salinity gradient in the Isonzo/Soča River mouth suggested flocculation of $\mathrm{Al}$ and $\mathrm{Ba}$ and desorption of $\mathrm{V}, \mathrm{Co}, \mathrm{As}, \mathrm{Se}, \mathrm{Cs}, \mathrm{U}$, and $\mathrm{Hg}$ from the riverine particles with increasing ionic strength while $\mathrm{Fe}, \mathrm{Mn}, \mathrm{Cu}, \mathrm{Cr}, \mathrm{Ni}, \mathrm{Zn}, \mathrm{Cd}$, and $\mathrm{Pb}$ did not correlate with salinity. These results can contribute to a better understanding of the temporal dynamics of COM, as an important metal carrier, in coastal waters affected by the metal-contaminated river inflows. Since the colloidally bonded metal(loid)s can be less bioavailable to plankton these data can help to establish their levels at the base of the coastal/estuarine food web at the onset of marine bioaccumulation.

Acknowledgements The authors appreciate the financial support that came from Slovene Research Agency. The author would like to thank Dr. Tea Zuliani for analyses of dissolved metal(loid)s.

\section{References}

Aiken G (2006) Challenges in the study of mercury-dissolved organic matter interactions. In: 8th international conference on mercury as a global pollutant, Madison, USA, p 535

Aluwihare LI, Repeta DJ, Chen RF (1997) A major biopolymeric component to dissolved organic carbon in surface sea water. Nature 387:166-169

Alvarado Quiroz NG, Hung C-C, Santschi PH (2006) Binding of thorium (IV) to carboxylate, phosphate and sulfate functional groups from marine exopolymeric substances (EPS). Mar Chem 100:337-353

Benner R, Pakulski JD, Mc Carthy M, Hedges JI, Hatcher PG (1992) Bulk chemical characterization of dissolved organic matter in the ocean. Science 255:1561-1564

Bonzongo J-C, Lyons WB, Hines ME, Warwick JJ, Faganeli J, Horvat M, Lechler PJ, Miller JR (2002) Mercury in surface waters of three mine-dominated river systems: Idrija River, Slovenia; Carson River, Nevada; and Madeira River, Brazilian Amazon. Geochem Expl Environ Anal 2:111-119

Bratkič A, Tinta T, Koron N, Guevara SR, Begu E, Barkay T, Horvat M, Falnoga I, Faganeli J (2018) Mercury transformations in a coastal water column (Gulf of Trieste, northern Adriatic Sea). Mar Chem 200:57-67

Covelli S, Piani R, Kotnik J, Horvat M, Faganeli J, Brambati A (2006) Behaviour of Hg species in a macrotidal deltaic system. The Isonzo River mouth (northern Adriatic Sea). Sci Tot Environ 368:210-223

Cozzi S, Falconi C, Comici C, Čermelj B, Kovac N, Turk V, Giani M (2012) Recent evolution of river discharges in the Gulf of Trieste (Northern Adriatic Sea) and their potential responses to anthropogenic pressure and climate changes. Estuar Coast Shelf Sci 115:14-24

De Vittor C, Paoli A, Fonda Umani S (2008) Dissolved organic carbon variability in a shallow coastal marine systems (Gulf of Trieste, northern Adriatic Sea). Estuar Coast Shelf Sci 78:280-290 
Donat JR, Bruland KW (1995) Trace elements in the oceans. In: Salibu B, Steinnes E (eds) Trace elements in natural waters. CRC Press, Boca Raton, pp 247-292

Doucet FJ, Lead JR, Santschi PH (2007) Colloid-trace element interactions in acquatic systems. In: Wilkinson JR, Lead JR (eds) Environmental colloids and particles behaviour, separation and characterisation. Wiley, Chichester, pp 95-195

Engel A, Handel N (2011) A novel protocol for determining the concentration and composition of sugars and particulate and high molecular dissolved organic matter (HMW DOM) in sea water. Mar Chem 127:180-191

Faganeli J, Herndl GJ (1991) Dissolved organic matter in the waters of the Gulf of Trieste (Northern Adriatic). Thalasssia Jugosl 23:51-63

Faganeli J, Horvat M, Covelli S, Fajon V, Logar M, Lipej L, Cermelj B (2003) Mercury and methylmercury in the Gulf of Trieste (northern Adriatic Sea). Sci Total Environ 304:315-326

Faganeli J, Ogrinc N, Kovac N, Kukovec K, Falnoga I, Mozetic P, Bajt O (2009) Carbon and nitrogen isotope composition of particulate organic matter in relation to mucilage formation in the northern Adriatic Sea. Mar Chem 114:102-109

Filella M (2007) Colloidal properties of submicron particles in natural waters. In: Wilkinson JK, Lead JR (eds) Environmental colloids and particles (behavior, separation and characterisation). Wiley, Chichester, pp 17-94

Fitzgerald WF, Lamborg CH, Hammerschmidt CR (2007) Marine biogeochemical cycling of mercury. Chem Rev 107:641-662

Fonda Umani S, Del Negro P, Larato C, De Vittor C, Cabrini M, Celio M, Falconi C, Tamberlich F, Azam F (2007) Major inter-annual variations in microbial dynamics in the Gulf of Trieste (northern Adriatic Sea) and their ecosystem implications. Aquat Microb Ecol 46:163-175

Gaillardet J, Viers J, Dupre B (2003) Trace elements in river waters. In: Heinrich DH, Karl KT (eds) Treatise on geochemistry. Pergamon, Oxford, pp 225-272

Graham AM, Aiken GR, Gilmour CC (2012) Dissolved organic matter enhances microbial mercury methylation under sulfidic conditions. Environ Sci Technol 46:2715-2723

Guentzel JL, Powell RT, Landing WM, Mason RP (1996) Mercury associated with colloidal material in an estuarine and open-ocean environment. Mar Chem 98:177-188

Guo L, Santschi PH (1997) Composition and cycling of colloids in marine environments. Rev Geophys $35: 17-40$

Guo L, Santschi PH (2007) Ultrafiltration and its applications to sampling and characterisation of aquatic colloids. In: Wilkinson JK, Lead JR (eds) Environmental colloids and particles (behavior, separation and characterisation). Wiley, Chichester, pp 159-221

Guo L, Santschi PH, Warnken KW (2000) Trace metal composition of colloidal organic material in marine environments. Mar Chem 70:257-275

Han S, Gill GA, Lehman RD, Choe K-Y (2006) Complexation of mercury by dissolved organic matter in surface waters of Galveston Bay, Texas. Mar Chem 98:156-166

Hertkorn N, Benner R, Frommberger M, Schmitt-Kopplin P, Witt M, Kaiser K, Kettrup A, Hedges JI (2007) Characterization of a major refractory component of marine dissolved organic matter. Geochim Cosmochim Acta 70:2990-3010

Hines ME, Horvat M, Faganeli J, Bonzongo J-C, Barkay T, Major E, Scott KJ, Bailey EA, Warwick JJ, Lyons WB (2000) Mercury biogeochemistry in the Idrija River, Slovenia, from above the mine into the Gulf of Trieste. Environ Res 83:129-139

Hiraide M, Hiramatsu S, Kawaguchi H (1994) Evaluation of humic complexes of trace metals in river water by adsorption on indium-trapped XAD-2 resin and DAEA- Sepahdex A-25 anion exchanger. Fresenius J Anal Chem 348:758-761

Hoefs J (2009) Stable isotope geochemistry. Springer, Berlin, p 285

Horvat M, Miklavčič V, Pihlar B (1991) Determination of total mercury in coal fly ash by gold amalgamation cold vapour atomic absorption spectrometry. Anal Chim Acta 243:71-79

Horvat M, Jereb V, Fajon V, Logar M, Kotnik J, Faganeli J, Hines ME, Bonzongo J-C (2002) Mercury distribution in water, sediment and soil in the Idrijca and Soča river systems. Geochem Expl Environ Anal 2:287-296

Hunter RC, Beveridge TJ (2008) Metal-bacteria interactions at both the planktonic cell and biofilm levels. In: Sigel AA et al (eds) Metal ions in life sciences. Wiley, Chichester, pp 127-165

Klun K, Šket P, Falnoga I, Faganeli J (2015) Variation in colloidal organic matter composition in coastal waters (Gulf of Trieste, northern Adriatic Sea). Geomicrobiol J 32:609-615

Koron N, Faganeli J, Falnoga I, Mazej D, Klun K, Kovac N (2013) Association of macroaggregates and metals in coastal waters. Mar Chem 157:185-193 
Kovac N, Bajt O, Faganeli J, Sket B, Orel B (2002) Study of macroaggregate composition using FT-IR and ${ }^{1}$ H-NMR spectroscopy. Mar Chem 78:205-215

Lam B, Baer A, Alaee M, Lefebvre B, Moser A, Williams A, Simpson AJ (2007) Major structural components in freshwater dissolved organic matter. Environ Sci Technol 41:8240-8246

Lamborg CH, Fitzgerald W, Skoog A, Visscher PT (2004) The abundance and source of mercury-binding organic ligands in Long Island Sound. Mar Chem 90:151-163

Lipizer M, De Vittor C, Falconi C, Comici C, Tamberlich F, Giani M (2012) Effects of intense physical and biological forcing factors on CNP pools in coastal waters (Gulf of Trieste, Northern Adriatic Sea). Estuar Coast Shelf Sci 115:40-50

Midorikawa T, Tanoue E (1998a) Molecular masses and chromophoric properties of dissolved organic ligands for copper (II) in oceanic water. Mar Chem 98:156-166

Midorikawa T, Tanoue E (1998b) Molecular masses and chromophoric properties of dissolved organic ligands for copper(II) in ocean water. Mar Chem 62:219-239

Miller CL, Mason RP, Gilmour CC, Heyes A (2007) Influence of dissolved organic matter on the complexation of mercury sulfide under sulfidic conditions. Environ Toxicol Chem 26:624-633

Millero FJ (2006) Chemical oceanography. CRC Taylor \& Francis, Boca Raton

Mopper K, Stubbins A, Ritchie JD, Bialk HM, Hatcher PG (2007) Advanced instrumental approaches for characterization of marine dissolved organic matter: extraction techniques, mass spectrometry, and nuclear magnetic resonance spectroscopy. Chem Rev 107:419-442

Morel FMM, Price N (2003) The biogeochermical cycle of trace metals in oceans. Science 300:944-947

Mozetič P, France J, Kogovšek T, Talaber I, Malej A (2012) Plankton trends and community changes in a coastal sea (northern Adriatic): bottom-up versus top-down control in relation to environmental drivers. Estuar Coast Shelf Sci 115:138-148

Oursel B, Garnier C, Durrieu G, Mounier S, Omanović D, Lucas Y (2013) Dynamics and fates of trace metals chronically input in a Mediterranean coastal zone impacted by a large urban area. Mar Pollut Bull 69:137-149

Posedel N, Faganeli J (1991) Nature and sedimentation of suspended particulate matter during density stratification in shallow coastal waters (Gulf of Trieste, northern Adriatic). Mar Ecol Prog Ser 77:135-145

Quigley MS, Santschi PH, Hung C-C, Guo L, Honeyman BD (2002) Importance of acid polysaccharides for ${ }^{234} \mathrm{Th}$ complexation to marine organic matter. Limnol Oceanogr 47:367-377

Ravichandran M (2004) Interactions between mercury and dissolved organic matter-a review. Chemosphere 55:319-331

Repeta DJ, Quan TM, Aluwihare LI, Accardi A (2002) A comparison of chemical characteristics of high molecular weight dissolved organic matter in fresh and marine waters. Geochim Cosmochim Acta 66:955-962

Sanudo Wilhelmy SA, Rivera-Duarte I, Russell Flegal A (1996) Distribution of colloidal trace metals in the San Francisco Bay Estuary. Geochim Cosmochim Acta 60:4933-4944

Schartup AT, Ndu U, Balcom PH, Mason RP, Sunderland EM (2015) Contrasting effects of marine and terrestrially derived dissolved organic matter on mercury speciation and bioavailability in seawater. Environ Sci Technol 49:5965-5972

Skyllberg U (2012) Chemical speciation of mercury in soil and sediments. In: Liu G et al (eds) Environmental chemistry and toxicology of mercury. Wiley, Chichester, pp 219-258

Solidoro C, Bastianini M, Bandelj V, Codermatz R, Cossarini G, Melaku Canu D, Ravagnan E, Salon S, Trevisani S (2009) Current state of, scales of variability, and trends of biogeochemical properties in the northern Adriatic Sea. J Geophys Res 114:C07591

Stolpe B, Guo L, Shiller AM, Hassellow M (2010) Size and composition of colloidal organic matter and trace elements in the Mississippi River, Pearl River and the northern Gulf of Mexico, as characterized by flow field-flow fractionation. Mar Chem 118:119-128

Stordal MC, Gill G, Wen L-S, Santschi PH (1996) Mercury phase speciation in the surface waters of three Texas estuaries: Importance of colloidal forms. Limnol Oceanogr 41:52-61

Sugimura Y, Suzuki Y (1988) A high temperature catalytic oxidation method for the determination of non-volatile dissolved organic carbon in seawater by direct injection of liquid sample. Mar Chem 24:105-131

Tang D, Warnken KW, Santschi PH (2002) Distribution and partitioning of trace metals $(\mathrm{Cd}, \mathrm{Cu}, \mathrm{Ni}, \mathrm{Pb}$, $\mathrm{Zn}$ ) in Galveston Bay waters. Mar Chem 78:29-45

Tinta T, Vojvoda J, Mozetič P, Talaber I, Vodopivec M, Malfatti F, Turk V (2014) Bacterial community shift is induced by dynamic environmental parameters in a changing coastal ecosystem (northern Adriatic, northeastern Mediterranean Sea)—a 2-year time-series study. Environ Microbiol 17:3581-3596

van Leeuwen HP, Buffle J (2009) Chemodynamics of aquatic metal complexes: from small ligands to colloids. Environ Sci Technol 43:7175-7183 
Verdugo P, Alldredge AL, Azam F, Kirchman DL, Passow U, Santschi PH (2004) The oceanic gel phase: a bridge in the DOM-POM continuum. Mar Chem 92:67-85

Wells ML (2002) Marine colloids and trace metals. In: Hansell DA, Carlson CA (eds) Biogeochemistry of marine dissolved organic matter. Elsevier, Amsterdam, pp 367-397

Wen L-S, Santschi PH, Tang D (1997) Interaction between radioactively labelled colloids and natural particles: evidence for colloidal pumping. Gechim Cosmochim Acta 61:2867-2878

Wen L-S, Santschi PH, Gill G, Paternostro C (1999) Estuarine trace metal distributions in Galveston Bay: importance of colloidal forms in the speciation of the dissolved phase. Mar Chem 63:185-212

Xia K, Skyllberg UL, Bleam WF, Bloom PR, Helmke PA (1999) X-ray absorption spectroscopic evidence for the complexation of $\mathrm{Hg}$ (II) by reduced sulfur in soil and humic substances. Environ Sci Technol 43:257-261

Publisher's Note Springer Nature remains neutral with regard to jurisdictional claims in published maps and institutional affiliations. 